\title{
NEOGLACIATION IN THE SOUTHERN KENAI MOUNTAINS, ALASKA
}

\author{
by
}

\author{
Gregory C. Wiles and Parker E. Calkin
}

(University at Buffalo, 4240 Ridge Lea Road, Buffalo, NY 14226, U.S.A.)

\section{ABSTRACT}

A preliminary late-Holocene glacial chronology from the west flank of the southern Kenai Mountains, Alaska, is characterized by two major episodes of advance. Outlet glaciers of both the Harding Icefield and the GrewingkYalik ice complex were expanding across their present positions at 545 A.D. and again during the Little Ice Age, about 1500 A.D. The earliest of these Neoglacial advances is dated by radiocarbon ages from the outer rings of tree trunks rooted near the margins of Grewingk and Dinglestadt glaciers. Subsequently, ice margins retreated some distance behind their present positions allowing marked soil development before the last readvance through mature forest. Wood preserved in lateral moraines at Grewingk Glacier and from an uprooted stump at Tustemena Glacier date this later ice advance. Tree-ring ages, correlated with lichen diameters, suggest that this last advance was widespread and culminated in its Neoglacial maximum about 1800 A.D.. Since this time, glacier retreat has dominated in the area, punctuated by at least two pauses. Historical accounts and photographs document a mean rate of retreat of $27 \mathrm{~m} \mathrm{a}^{-1}$ for the past century with partial control exerted by calving of ice margins into proglacial lakes.

\section{INTRODUCTION}

This paper presents a late-Holocene history of glacial variation at the west flank of icefields in the southern Kenai Mountains, south central Alaska. The sequence is derived from studies made in 1988 near six west-trending outlet tongues of the Harding Icefield and Grewingk-Yalik ice complex. These include, from south to north, the Wosnesenski, Grewingk, Portlock, Goat (unofficial name), Dinglestadt and Tustemena glaciers (Fig. 1, 1-6). The movements of these tongues, which are land-based and nonsurging, have repeatedly displaced forest and built icemarginal structures so that mapping, with radiocarbon, dendrochronologic and lichenometric techniques, allows interpretation of a record of glacier fluctuation and potentially of climatic change.

\section{Setting}

The southern Kenai Mountains are dominated by two icefields, which are drained by 38 distinct outlet glaciers, including seven that reach tidewater in fjords on the east mountain flank. Elevations of the icefields reach from 900 to $1800 \mathrm{~m}$ and are interspersed with peaks higher than $2000 \mathrm{~m}$ altitude.

The icefields intercept an estimated precipitation of 3 to $10 \mathrm{~m} \mathrm{a}^{-1}$ (Rice, 1987) from moisture-laden, Pacific air masses that move westward from the Gulf of Alaska. Over $50-70 \%$ may be snow (Clagett, 1988). However, the town of Homer, just west of our study area within the western precipitation shadow of the mountains, receives only $0.6 \mathrm{~m} \mathrm{a}^{-1}$ of precipitation; mean annual temperature is $2.7^{\circ} \mathrm{C}$ (Ruffner and Bair, 1987). A coastal forest of Sitka spruce and minor hemlock rims the Kenai Peninsula, reaching from tidewater to an altitude of about $700 \mathrm{~m}$.

The southern Kenai Mountains are underlain by graywacke and greenstones representing trench and melange

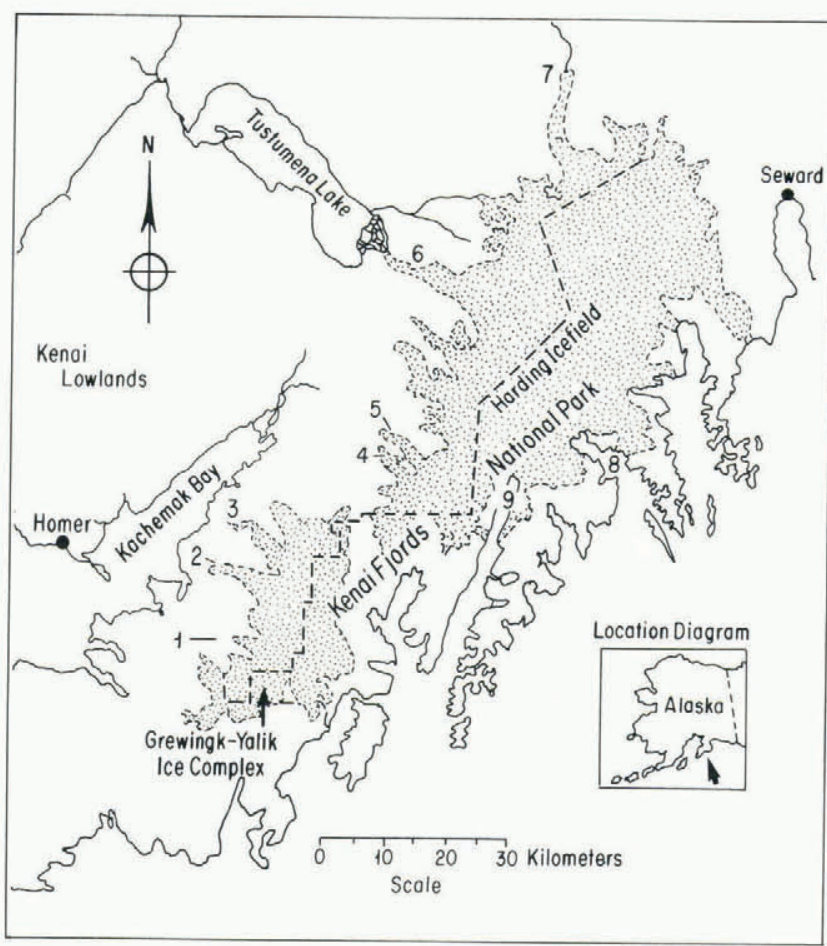

Fig. 1. Index map of the southern Kenai Peninsula. Numbers refer to the following glaciers: (1) Wosnesenski; (2) Grewingk; (3) Portlock; (4) Goat; (5) Dinglestadt; (6) Tustemena; (7) Skilak; (8) Northwestern; (9) McCarty.

sequences thrust up as a Mesozoic forearc ridge (Kelley, 1985). Recent tectonic activity has resulted in as much as $100 \mathrm{~m}$ of subsidence since Wisconsin time on the east side of the area as illustrated by shoreline changes and submerged cirques; this includes 1 to $2 \mathrm{~m}$ of subsidence resulting from the 1964 Alaskan earthquake (Plafker, 1969).

\section{Late Pleistocene-Holocene deglaciation}

The withdrawal of the Cordilleran ice sheet and of glacier tongues from the Kenai Mountains is poorly established (Hamilton and Thorson, 1983). Karlstrom (1964) inferred that deglaciation started about 9000 years B.P. following his Naptowne Glaciation. However, a core from Hidden Lake, $10 \mathrm{~km}$ northwest of Skilak Glacier (Fig. 1) suggests deglaciation was underway by about 14500 years B.P. (Rhymer and Sims, 1982). Pollen data supports this, but Ager (1983) suggests deglaciation may not have started until 10500 years B.P. along the eastern coast of the Kenai Mountains.

In the study area well-preserved but lichen-covered end moraines in ice-free, southwest-facing cirques occur with relic patterned ground between 700 and $1300 \mathrm{~m}$ altitude. These may be evidence of formerly lower snowlines, permafrost (Bailey, 1981) and long subaerial exposure without major ice cover since late-Pleistocene time. 
TABLE I. ${ }^{14} \mathrm{C}$ AGES FROM THE SOUTHERN KENAI MOUNTAINS

\begin{tabular}{lccccc} 
Laboratory no. & $\begin{array}{c}\text { Uncalibrated age } \\
\text { year B.P. }\end{array}$ & $\begin{array}{c}\text { Glacier in } \\
\text { (Fig. 1) }\end{array}$ & \multicolumn{2}{c}{$\begin{array}{c}\text { Calibrated interval } \\
\text { year A.D. }\end{array}$} \\
\hline BGS 1271 & $1440 \pm 70$ & min & mean & max \\
BGS 1272 & $440 \pm 120$ & 2 & 450 & 545 & 640 \\
BGS 1273 & $360 \pm 70$ & 2 & 1335 & 1488 & 1640 \\
BGS 1277 & $260 \pm 70$ & 2 & 1415 & 1530 & 1645 \\
BGS 1278 & $1440 \pm 70$ & 2 & 1490 & 1643 & 1795 \\
BGS 1279 & $8400 \pm 100$ & 5 & 450 & 545 & 640 \\
Beta-29944 & $360 \pm 70$ & beyond range & of calibration curve \\
L-117K** & $400 \pm 150$ & 2 & 1415 & 1530 & 1645 \\
UW-512* & $1500 \pm 90$ & 6 & 1325 & 1563 & 1800 \\
UW-515* & $1635 \pm 100$ & 12 & 265 & 453 & 640 \\
UW-516* & $1385 \pm 55$ & 11 & 80 & 338 & 595
\end{tabular}

Radiocarbon ages, which are all from separate localities, are calibrated after Klein and others (1982).

* ages from Post (1980a and b).

** age from Karlstrom (1964).

The only direct evidence of an early-Holocene ice position in the southern Kenai Mountains is an age of wood found in a glacio-lacustrine deposit $5 \mathrm{~km}$ south of Grewingk Glacier. It indicates that ice had retreated from the adjacent uplands and ice margins were at least $10 \mathrm{~km}$ east of the coast of Kachemak Bay by 8400 years B.P. (Table I).

\section{DATING METHODS}

Recent retreat of Kenai Mountain glaciers has uncovered a wide variety of glacial deposits with forest debris, in-situ tree trunks and buried soils produced by multiple advances into forest. Seven radiocarbon dates on wood, obtained during this study and others from previous work (Karlstrom, 1964: Table I; Post, 1980a and b), help define the glacial history. Ages are reported in the text below as calibrated radiocarbon years A.D. from Table I.

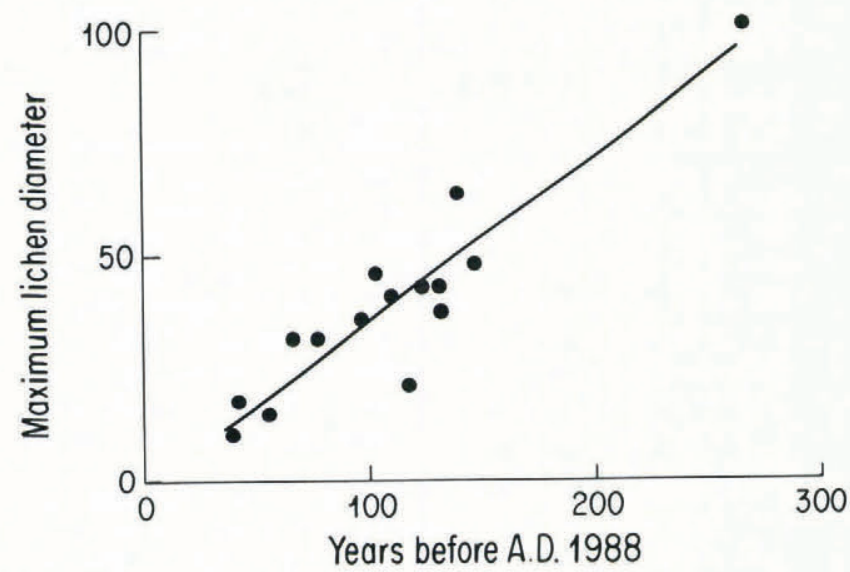

Fig. 2. Preliminary lichen curve for the west flank of the southern Kenai Mountains. Lichen sizes are calibrated by tree ages.
The times of ice removal from moraines were estimated from ring counts of the oldest tree growing on the landform as corrected by an estimate of tree establishment (ecesis) time. Ecesis intervals at Grewingk, Wosnesenski and Portlock glaciers averaged 14 years based on mapping and historical data. Ecesis intervals may be somewhat shorter on lateral moraines adjacent to mature forest, and longer in the forefields of Dinglestadt and Tustemena glaciers (Fig. 1), which are higher and farther from the coast.

The abundance of trees growing on many surfaces together with the nearly ubiquitous occurrence of the lichen Rhizocarpon section Alpicola on adjacent non-forested rock surfaces afford minimum ages for most moraines. Control points for a preliminary lichen growth rate curve (Fig. 2) were determined by measuring maximum lichen diameters to the nearest millimeter on surfaces approximately dated by tree rings. Average lichen growth rate, calibrated in this

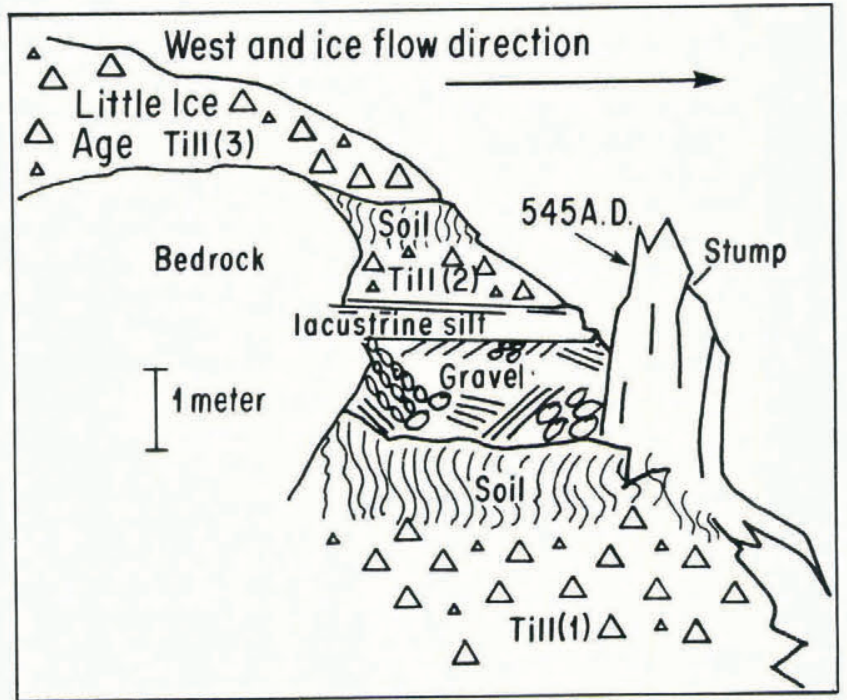

Fig. 3. Composite diagram of the depositional history near the present margin of Dinglestadt Glacier. 
manner through 250 years, was $0.37 \mathrm{~mm} \mathrm{a}^{-1}$; this is similar to growth rates of lichen in similar climatic settings (Locke and others, 1979.

\section{NEOGLACIATION}

\section{Early advance}

About 545 A.D. the outermost margins of the glaciers under investigation were actively advancing near their present-day positions. Ages for this event were obtained from radiocarbon analyses of in-situ tree stumps (Table I) within $1 \mathrm{~km}$ of the termini of Grewingk and Dinglestadt glaciers (Fig. 1).

A composite depositional section of the buried forest at Dinglestadt Glacier (Fig. 3) records a complex history; the setting at Grewingk Glacier is obscured by recent alluvium. Soil of the paleoforest floor was developed in till (till 1) overlying bedrock. It is characterized by a $13 \mathrm{~cm}$ eluviated horizon capping an oxidized and strongly-colored interval of at least $60 \mathrm{~cm}$. Tree stumps are buried by either a unit of gravel, sand and silt, or by till (till 2) (Fig. 3). An upper soil is developed in these units. This soil appears less well developed than the lower one, although it is apparent through $40 \mathrm{~cm}$ and is capped by a few $\mathrm{cm}$ of organic material. The younger soil is overlain by a till (till 3), which forms the local surface and is assigned to a later advance discussed below.

We interpret this section to indicate soil development and forest growth during a relatively warm interval prior to about 545 A.D., such as recorded elsewhere at this time in Alaska (Calkin, 1988). The occurrence of in-situ tree trunks, of about a meter thickness, near present ice margins of both Grewingk and Dinglestadt glaciers suggests a more extensive forest cover prior to 545 A.D. than presently exists. The forest appears to have been buried by outwash and overridden by advancing ice. Ages of 545 A.D. (Table I) at two locations near present ice margins indicate synchronous advances, at least by these two valley glaciers $40 \mathrm{~km}$ apart (Fig. 1).

The extent of this ice-marginal advance beyond the buried forests is uncertain; however it was probably less than subsequent ice expansions, based on stratigraphic and relative dating studies. The upper soil (Fig. 3) records an interval of ice-marginal recession at least as great as that of the present.

\section{Little Ice Age advance}

As early as 1488 A.D. the study glaciers were once again advancing into forest. The initial date of this event is determined by radiocarbon ages on wood incorporated in two lateral moraines at Grewingk Glacier and in an end moraine at Tustemena Glacier (Karlstrom, 1964). The age of trees (about 150 years) and lichen diameters (about $60 \mathrm{~mm}$ ) suggest that retreat from terminal positions occurred during the early to middle 19th century.

At Grewingk Glacier, three ages were obtained from lateral moraines that coincide with outermost trimlines. The oldest of these calibrated ages, 1488 A.D., was of wood in glaciofluvial deposits interfingered with an uppermost diamicton unit in the southern lateral moraine. Stratigraphically younger (or contemporaneous) compact red diamicton incorporating up to $30 \%$ wood and forest debris also occurs in this moraine, as well as at a comparable position in the lateral moraine on the north valley wall. Both of the red diamicton occurrences yielded ages of 1530 A.D. (Table I). The red diamicton is interpreted as a basal till documenting ice advance through a forest.

At Tustemena Glacier Karlstrom (1964) obtained an age of 1563 A.D. from a $\log$ in till of the younger of a pair of closely associated end moraines near the present ice margin. He considered this age to be a maximum for the inner moraine (Karlstrom's Tunnel II), and inferred the outer ridge (Karlstrom's Tunnel I) to be much older, based on correlation with deposits in the northern Kenai Mountains. However, similarly-grouped end moraines occur at the glaciers studied south of Tustemena Glacier. Their lichenometric and dendrochronologic dates, as well as the numerical dates (Table I) at Grewingk Glacier, suggest the 1563 A.D. Tustemena age is a close maximum for the initial advance associated with the outer moraine of the pair.
The outermost ice positions associated with the radiocarbon-dated deposits at Grewingk and Tustemena glaciers appear to be marked by discontinuous terminal moraines on the glacier forefields. These moraines and similar ones of the other four glaciers coincide with projected trimlines. They also appear to represent Holocene maxima.

A minimum date of 1835 A.D. (139 tree rings plus 14 year ecesis estimate) for ice removal from the lateral moraine at Grewingk Glacier is based on coring a Sitka spruce on the moraine. The present retreat began in 1858 A.D. or earlier from the Grewingk terminal moraine, while retreat at the comparable moraine at Tustemena Glacier began by 1867 A.D. Tree-ring ages suggest that retreat at Portlock and Wosnesenski glaciers began by 1848 and 1828 A.D. respectively. At Dinglestadt Glacier and nearby Goat Glacier, retreat and stabilization determined from lichen ages occurred by about 1824 and 1799 A.D. respectively. The data above suggest that ice margins invaded forests and reached terminal positions as early as 1488-1530 A.D. They probably remained at or near these positions until the late or middle 19th century.

Rates of retreat since the time of the Little Ice Age maxima to 1900 A.D. average $8 \mathrm{~m} \mathrm{a}^{-1}$, based on tree-ring and lichen data collected from recessional moraines for all glaciers. The mean rate of retreat between 1900 and 1988 increased to about $27 \mathrm{~m} \mathrm{a}^{-1}$ (Fig. 4). Observations by Dall (1880) and Gilbert (1904) at Grewingk Glacier suggest that rapid retreat may have begun as early as 1895 A.D. Gilbert (1904) reported retreat of Grewingk Glacier between 1880 and 1895 A.D. to be $6 \mathrm{~m} \mathrm{a}^{-1}$, and almost $30 \mathrm{~m} \mathrm{a}^{-1}$ between 1895 and 1899 A.D..

\section{DISCUSSION AND CORRELATION}

Figure 4 summarizes our current information on Holocene glacier fluctuation in the southern Kenai Mountains based on representative histories at Grewingk and Dinglestadt glaciers. The moraines of the Little Ice Age appear to be the Holocene maximum at all glacier forefields in the study area. A well-defined, undated moraine along

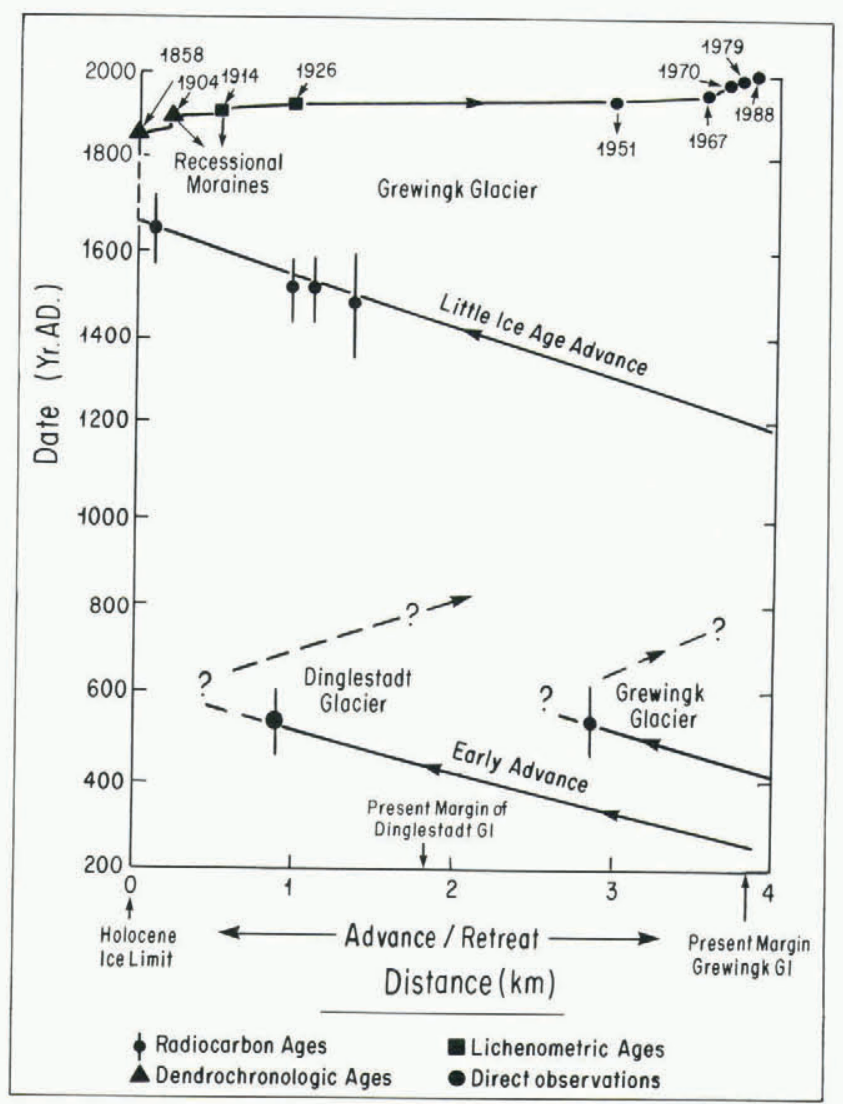

Fig. 4. Neoglacial history of Grewingk and Dinglestadt glaciers, which also represent the general sequence of Holocene glaciation on the west flank of the southern Kenai Mountains. 


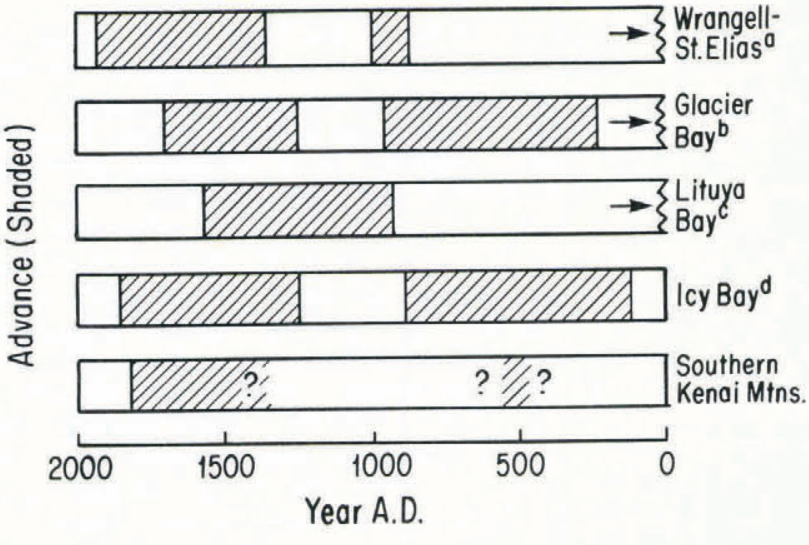

Fig. 5. Comparison of Neoglacial history (last 2000 years) of the southern Kenai Mountains with histories of other areas in southern Alaska. Sources: (a) Denton and Karlen, 1977, (b) Goodwin, 1988, (c) Mann and Ugolini, 1985, (d) Porter, in press.

the east margin of Tustemena Lake, and other remnants, all identified by Karlstrom (1964) as Holocene deposits, may represent late-Pleistocene events.

Glacial fluctuations in the fjords on the east flank of the southern Kenai Mountains appear to show similarities with the sequence presented in this paper. For example, Post (1980a and b) has obtained ages from sheared, rooted stumps that record ice advance near the present margins of McCarty Glacier about 453 A.D. and Northwestern Glacier at 338 and 665 A.D. Post also determined that these were at their outermost Neoglacial moraines during the 19th century prior to major recession.

The Neoglacial sequence of the southern Kenai Mountains, although as yet incompletely understood, is similar to the late-Holocene glacial record elsewhere in Alaska (Calkin, 1988) (Fig. 5). This includes widespread glacial recession for several centuries starting about 0 A.D. and two major periods of glacial advance separated by a recession centered on 1000 to 1200 A.D. (Goldthwait, 1966; Denton and Karlen, 1977; Mann and Ugolini, 1985; Porter, in press). Retreat from Little Ice Age maxima across the study area has accelerated since 1900, possibly reflecting increased warming (Field, 1975) and/or the development of proglacial lakes in front of receding margins.

\section{ACKNOWLEDGEMENTS}

We are indebted to $T$. Hamilton for suggesting the research, as well as to E. Muller and D. Pair for their contributions to fieldwork and problem solving. Excellent logistic support was provided by W. Workman, the Kachemak Bay State Park rangers, and the Pratt Museum of Homer. This paper is an outgrowth of research partially supported by Division of Polar Programs, National Science Foundation.

\section{REFERENCES}

Ager, T.A. 1983. Holocene vegetational history of Alaska. In Wright, H.E., ed. Late Quaternary environments of the United States. Minneapolis, MN, University of Minnesota Press, 128-141.

Bailey, P.K. 1981. Periglacial features in the southern Kenai
Mountains of southcentral Alaska. Geol. Soc. Am. Abstr. Progs., 13(7), 401.

Calkin, P.E. 1988. Holocene glaciation of Alaska (and adjoining Yukon Territory, Canada). Quat. Sci. Rev., 7(2), 159-184.

Clagett, G.P. 1988. Alaska snow surveys. 1988 annual data summary. Anchorage, AK, United States Department of Agriculture. Soil Conservation Service.

Dall, W.H. 1880. Pacific coast pilot: coasts and islands of Alaska. Map. Washington, U.S. Coast and Geodetic Survey.

Denton, G.H. and W. Karlén. 1977. Holocene glacial and tree-line variations in the White River Valley and Skolai Pass, Alaska and Yukon Territory. Quat. Res., 7(1), 63-111.

Field, W.O. 1975. Glaciers of the Kenai Mountains, Alaska. In Field, W.O., ed. Mountain glaciers of the Northern Hemisphere. Vol. 2. Hanover, NH, Cold Regions Research and Engineering Laboratory, 493-541.

Gilbert, G.K. 1903. Harriman Alaska Expedition. Alaska, Vol. III. Glaciers and glaciation. New York, Doubleday, Page and Company.

Goldthwait, R.P., and 8 others. 1966. Soil development and ecological succession in a deglaciated area of Muir Inlet, southeast Alaska. Ohio State Univ. Inst. Polar. Stud. Rep. 20.

Goodwin, R.G. 1988. Holocene glaciolacustrine sedimentation in Muir Inlet and ice advance in Glacier Bay, Alaska, U.S.A. Arct. Alp. Res., 20(1), 55-69.

Hamilton, T.D. and R.M. Thorson. 1983. The Cordilleran ice sheet in Alaska. In Porter, S.C., ed. LateQuaternary environments of the United States. The Late Pleistocene. Minneapolis, MN, University of Minnesota Press, 38-52.

Karlstrom, T.N.V. 1964. Quaternary geology of the Kenai Lowland and glacial history of the Cook Inlet region, Alaska. U.S. Geol. Surv. Prof. Pap. 443.

Kelley, J.S. 1985. Geologic setting of the Kenai Peninsula and Cook Inlet Tertiary basin, south-central Alaska. In Sisson, A., ed. Guide to the geology of the Kenai Peninsula, Alaska. Anchorage, AK, Alaska Geological Society, 3-19.

Klein, J., J.C. Lerman, P.E. Damon, and E.K. Ralph. 1982. Calibration of radiocarbon dates. Radiocarbon, 24(2), 103-150.

Locke, W.W., J.T. Andrews, and P.J. Webber. 1979. A manual for lichenometry. Tech. Bull. Br. Geomorphol. Res. Group., 26.

Mann, D.H. and F.C. Ugolini. 1985. Holocene glacial history of the Lituya District, southeast Alaska. Can. J. Earth Sci., 22(6), 913-928.

Plafker, G. 1969. Tectonics of the March 27, 1964 Alaska earthquake. U.S. Geol. Surv. Prof. Pap. 543-I.

Porter, S.C. In press. Late Holocene cycles of advance and retreat of the fjord glacier system in Icy Bay, Alaska. Arct. Alp. Res.

Post, A. 1980a. Preliminary bathymetry of McCarty Glacier, Alaska. U.S. Geol. Surv. Open File Report 80-424.

Post, A. 1980b. Preliminary bathymetry of Northwestern Fiord and neoglacial changes of Northwestern Glacier, Alaska. U.S. Geol. Surv. Open File Report 80-414.

Rice, B. Unpublished. Changes in the Harding Icefield, Kenai Peninsula, Alaska. (M.S. thesis, University of Alaska, 1987.)

Ruffner, J.A. and F.E. Bair. 1987. Weather of U.S. Cities, Detroit, MI, Gale Research Group.

Rymer, M.J. and J.D. Sims. 1982. Lake-sediment evidence for the date of deglaciation of the Hidden Lake area, Kenai Peninsula, Alaska. Geology, 10, 314-316. 